\title{
DEVELOPMENT OPPORTUNITIES OF RELIGIOUS TOURISM IN AZERBAIJAN IN THE CONDITIONS OF GLOBALIZATION
}

\author{
Natavan Mammadova ${ }^{1}$ \\ 'Baku Business University, \\ Baku, Republic of Azerbaijan
}

\begin{abstract}
:
Azerbaijan has large reserves of oil and gas, and therefore the fuel and energy sector occupies a significant place in its economy. Tourism development began receiving more attention in recent years. Azerbaijan is an Islamic state that has good potential for the development of religious tourism. The paper analyzes the present state of tourism in Azerbaijan, the potential and opportunities for the development of religious tourism, while special attention is paid to the influence of globalization on the development of tourism in accordance with the covenants of the Koran.
\end{abstract}

\section{Keywords:}

tourism, religion, Islam, globalization, Azerbaijan.

\section{INTRODUCTION}

In the modern world, tourism has become an almost necessary need of the mass consumer, and it is characterized by high development rates. Almost all countries are represented on the world tourism market, including Azerbaijan. However, tourism occupies an insignificant place in Azerbaijan's GDP. Azerbaijan possesses large reserves of oil and gas, thus the fuel and energy sector occupies a significant place in the economy of Azerbaijan. To prevent the Dutch disease, Azerbaijan needs to develop non-oil sectors and tourism, including religious tourism, which can play an important role. The purpose of this paper is to study the possibilities of developing religious tourism in Azerbaijan.

\section{RESULTS AND DISCUSSION}

Azerbaijan is a post-Soviet state with a population of 9,705,600 people. According to the 2009 population census, $91.6 \%$ of the total population of the country are Azerbaijanis (Azstat). Azerbaijan possesses large reserves of oil and gas. Therefore, the fuel and energy sector occupies a significant place in its economy. For more than 25 years of its independence, Azerbaijan is rapidly modernizing, the reforms have been successful and the 
Azerbaijan is an Islamic state, but despite that fact, the three major religions - Islam, Judaism and Christianity coexist peacefully for years in the country. In Soviet times, the state eradicated religion and replaced it with communist ideology for several decades. Following independence in Azerbaijan, as a result of rethinking the role of religion in the society, the religion penetrates deeper into the community and the number of believers is growing. The Law of the Republic of Azerbaijan "On Freedom of Religion" (1992) ensures the right of every person to determine and express his/her attitude towards religion, as well as to exercise this right (law). According to the current Constitution of the Republic of Azerbaijan (Constitution), every citizen has the freedom of conscience, the right to independently determine his/her attitude towards religion, to profess a religion in person or in a community with others or not to profess any religion, and to express and disseminate his/her beliefs related with his/her attitude towards religion. The Constitution also states that, in the Republic of Azerbaijan, the religion is separated from the state; all religions are equal before the law; it is forbidden to disseminate and propagate religions that humiliate human dignity and are contrary to the principles of humanity. Simultaneously, the state system of education is secular.

In Azerbaijan, Islam is represented by the movements of Shiites-Imamates, as well as Sunnis-Hanafi and Shafi'ites. During recent years, the "openness" of the republic has caused the penetration of a number of other religious trends and the Sufi sect into the country. In the process of Islamization of the sovereign Azerbaijan, there is an increasing veneration of saints and this, along with all other aspects, creates the basis for the development of religious tourism in the country. Religious tourism is an integral part of the modern tourism industry, whose role is constantly growing, both in the global and the national economy. This is facilitated by the growth of incomes of the population, the increase of spare time, the increase of openness of the regions, etc. Tourism contributes to the cultural integration of people and to respect for religions, traditions, customs, etc.

Tourism has existed for many centuries. In Azerbaijan, it began its development at the time of the Great Silk Road. At present, tourism is an entire industry, which has a multiplier effect, and contributes to the development of other sectors of the economy: transport, communications, trade, construction, agriculture, etc. Accordingly, tourism is a promising direction for structural reorganization of the country's economy. In 2016, the direct contribution of Travel \& Tourism to GDP was AZN 2,285.3 million (USD 1,437.3 million), 4.1\% of total GDP, and the indirect contribution was AZN
8,091.3 million (USD 5,088.9 million), $14.6 \%$ of GDP. It is directly supported by 171,000 jobs (3.7\% of total employment), and the total contribution to employment, including $13.2 \%$ of total employment (609,000 jobs). Visitor exports are AZN 4,552.2 million (USD 2,863.0 million), $16.9 \%$ of total exports in 2016 (WTTC).

In 2015, the number of enterprises in the tourism sector amounted to 243 units, which is 25 times higher than in 2006 and almost 2 times than in 2010. Number of employees engaged almost doubled from year 2006 (779 persons) to year 2015 (1,586 persons). In the same period, gross income of enterprises has increased more than 4 times from AZN 4.8 million to AZN 35.0 million. (Table 1) (AzStat).

The number of foreigners who visited Azerbaijan in 2015 amounted to 2,006,200, while the number of Azerbaijani citizens travelling abroad was 4,095,800. Out of the total number of foreigners, $1,921,900$ visited Azerbaijan for tourism purposes, 668,800 with the aim of resting, 632,300 for business tourism purposes, 36,500 for therapeutic tourism, and 11,500 - for the purpose of religious tourism. Tourism was the motive for 3,256,200 Azerbaijani citizens who went abroad last year, 1,045,200 of them with the aim of resting, the same number for the purpose of business tourism, 140,000 for medical tourism, 133,500 for religious tourism purpose (Rustamova, 2016).

Religious tourism is an integral part and a profitable form of modern tourism industry. The example of Saudi Arabia shows the potential of receiving tourists from other countries. Certainly, the hajj to Mecca of Saudi Arabia brings a huge income and Azerbaijan cannot compare with it, but the country has enough resources that can interest pilgrims - foreigners and its citizens. In Azerbaijan, religious holidays are also pilgrim holidays and they are held at the state level. These official holidays are declared as a day off from work, and believers are provided with all the necessary conditions for pilgrimage and rituals.

Azerbaijan has good potential for the development of religious tourism. Among them, the following mosques and churches should be noted:

- Juma mosque in Shamakhi, one of the oldest (second after Darband) and the largest, not only in Azerbaijan, but throughout the South Caucasus (more than 3,000 people can be admitted at the same time). According to some sources, this mosque was built in 743, when the Khazar Khan converted to Islam.

- Askhabi-Kahf is a complex of religious and cultural monuments located in a natural cave, $12 \mathrm{~km}$ 
from Nakhchivan. It is believed that the story of young men and a dog that slept for more than 300 years, which is told in the Surah of the Koran "Al-Kahf" ("Cave"), has taken place right here.

- The Shirvanshahs' palace in Baku. It is interesting to the Muslims who profess Shiism.

- The sanctuary of Mir Movsum Aga, one in Babadag, and one in Beylagan, the place of pilgrimage of Saint Jergis Prophet.

- Mausoleum of Alim Seyyid Yahya Bakuvi - many tourists from Turkey come here.

- The Nardaran mosque in Nakhchivan is a holy place since Noah's time, connected with the relatives of Imam Ali.
- The Church of St. Michael the Archangel in Baku is the oldest surviving church in the city, according to some sources, it was built between 1841 and 1849 by sailors who survived the shipwreck.

- The Catholic Church of the Immaculate Conception of the Blessed Virgin Mary in Baku - Pope John Paul II took part in the ceremony of laying the foundation for it in May 2002.

- The existing historical synagogues in Guba, in the village of Krasnaya Sloboda, are inhabited by one of the largest communities of Mountain Jews in the world.

- Temple of fire worshipers - Ateshgyah, in Surakhani region near Baku city, etc.

Table 1. Main indicators of tourism enterprises in azerbaijan

\begin{tabular}{|c|c|c|c|c|c|c|c|}
\hline & 2006 & 2010 & 2011 & 2012 & 2013 & 2014 & 2015 \\
\hline Number of enterprises & 96 & 126 & 141 & 170 & 197 & 218 & 243 \\
\hline $\begin{array}{l}\text { Number of employees } \\
\text { (including substitutes),person }\end{array}$ & 779 & 1418 & 1541 & 1730 & 1729 & 1,794 & 1,586 \\
\hline $\begin{array}{l}\text { number of employees engaged in tourism } \\
\text { activity, persons }\end{array}$ & 612 & 1159 & 1279 & 1473 & 1515 & 1,567 & 1,308 \\
\hline $\begin{array}{l}\text { Gross income of enterprises, thousand } \\
\text { manat }\end{array}$ & 8480.0 & 19065.3 & 22634.8 & 27121.5 & 29600.9 & $31,107.1$ & $36,482.2$ \\
\hline from tourism services & 4788.1 & 14755.5 & 17804.7 & 21597.1 & 24823.6 & $26,031.0$ & $35,079.6$ \\
\hline $\begin{array}{l}\text { Expenditures for product (service) } \\
\text { output - total, thousand manat }\end{array}$ & 7054.4 & 17811.3 & 20662.1 & 23540.8 & 25292.5 & $27,018.1$ & $30,811.6$ \\
\hline tourist services & 4094.3 & 13805.7 & 16065.6 & 18903.1 & 21818.2 & $25,708.6$ & $29,480.0$ \\
\hline $\begin{array}{l}\text { Number of trip sheets sold to population, } \\
\text { unit }\end{array}$ & 20256 & 34121 & 42583 & 62866 & 65448 & 66,233 & 44,615 \\
\hline $\begin{array}{l}\text { sold to Azerbaijan citizens for travelling } \\
\text { within the country - total, unit }\end{array}$ & 2634 & 3385 & 4045 & 5121 & 7078 & 6,990 & 4,695 \\
\hline $\begin{array}{l}\text { sold to Azerbaijan citizens for travelling } \\
\text { outside of the country - total, unit }\end{array}$ & 17385 & 27030 & 34254 & 52378 & 53771 & 54,900 & 38,002 \\
\hline $\begin{array}{l}\text { sold to foreign citizens for travelling within } \\
\text { Azerbaijan territory, unit }\end{array}$ & 237 & 3706 & 4284 & 5367 & 4599 & 4,343 & 1,918 \\
\hline $\begin{array}{l}\text { Value of trip sheets sold to population, } \\
\text { thousand manat }\end{array}$ & 7697.1 & 25848.7 & 29316.6 & 40693.2 & 42892.3 & $44,820.3$ & $33,474.7$ \\
\hline $\begin{array}{l}\text { sold to Azerbaijan citizens for travelling } \\
\text { within the country - total, thousand manat }\end{array}$ & 2270.8 & 1708.4 & 2021.1 & 3147.4 & 2747.9 & $2,764.0$ & $4,039.7$ \\
\hline $\begin{array}{l}\text { sold to Azerbaijan citizens for travelling out- } \\
\text { side of the country - total, thousand manat }\end{array}$ & 5375.8 & 19750.2 & 22583.4 & 33652.3 & 36991.0 & $39,708.5$ & $28,622.7$ \\
\hline $\begin{array}{l}\text { sold to foreign citizens for travelling within } \\
\text { Azerbaijan territory, thousand manat }\end{array}$ & 50.5 & 4390.1 & 4712.1 & 3893.4 & 3153.4 & $2,347.80$ & 812.3 \\
\hline $\begin{array}{l}\text { Number of received and dispatched tourists, } \\
\text { persons }\end{array}$ & 45605 & 69923 & 83620 & 101431 & 91961 & 92,305 & 61,965 \\
\hline
\end{tabular}

Source: http://www.stat.gov.az/source/tourism/indexen.php 
Tourism in Azerbaijan is developing under the influence of global factors and, first of all, the globalization, which increases the interconnection and interdependence of countries. In turn, tourism in the context of globalization deepens international contacts, promotes more complete exchange of cultural heritage of a particular country, which is very important for the development of tourism in general, and religious tourism in particular.

The present stage of development of the world is characterized by domination of the globalization processes, which transform and change the structure and operation parameters of the world economic system. The world economic community turns to the complete economic system which defines "game rules" for national economies. On a global scale, it promotes rationalization and optimization of use of all mankind resources, raises efficiency of separate branches and world economy as a whole, containing rather powerful synergetic effect, which leaves behind frameworks of the simple sum of optimizing factors.

The modern world has essentially changed, but it has not accurately settled rules. The process of forming the global community and its universal cultural values goes discrepantly. The reason for this could be found at the globalization of western liberal values, and first of all, values of the American culture which are unacceptable for other faiths, especially Islam. Under the influence of this westernization, the world goes towards a singlecrop society, and it causes serious conflicts not only between the countries, but also faiths. In this regard, the globalization should not be considered from the idea of unipolar world, but from its variety and first of all, from the multipolarity point of view. It is necessary to create opportunities for development of all existing civilizations. The idea of the unipolar world does not correspond to Holy Koran representations. As it is known, the modern world is inconsistent, since it is generated by differently oriented tendencies (internationalization and regionalization, globalization and localization) and stricken by biosocial contradictions. In such a world, the stability can be reached in the conditions of at least bipolar political system: "If God had not repelled some people by means of others, the earth would have been corrupted" (the Holy Koran, 2:251).

Globalization motives and purposes are based, first of all, on free movement of production factors, the goods and services, which get transnational character, and they are accompanied by export of ideas and values. Globalization is based on the idea of unity and equality. It declares "happiness for all and everyone". However, as practice shows, the equality is not present at all and possibilities for its achievement are limited. The aspiration of large states to have an absolute power over others, confirms the vitality of Holy Koran doctrine that equality will never be established between humans, peoples and civilizations. The reason is not in spiritual, but in material distinctions: "We distribute among them their livelihood in the life of this world, and We have exalted some of them above others in degrees, that some of them may take others in subjection; and the mercy of your Lord is better than what they amass" (the Holy Koran, 43:32). "if Allah had pleased He would have made you (all) a single people, but that He might try you in what He gave you, therefore strive with one another to hasten to virtuous deeds" (the Holy Koran, 5:48). By analyzing the history of the world community development, it could be concluded that material, cultural and confessional distinctions between human beings will never disappear, although they stimulate development of civilizations and create a basis for cooperation of countries.

According to the Holy Koran, all religions represent an uniform spiritual whole, created by God according to His coherent plan: "Surely We revealed the Taurat in which was guidance and light; with it the prophets who submitted themselves (to Allah) judged (matters) for those who were Jews... And We sent after them in their footsteps Isa, son of Mariam, verifying what was before him of the Taurat and We gave him the Injeel in which was guidance and light... And We have revealed to you the Book with the truth, verifying what is before it of the Book and a guardian over it, therefore judge between them by what Allah has revealed, and do not follow their low desires (to turn away) from the truth that has come to you; for every one of you did We appoint a law and a way" $(5: 44,46,48)$. Thereby the Holy Koran concerns people of the Holy Writ as members of a uniform family indulged by the Supreme".

It is important to notice that the idea of unity was first proclaimed by the religion and therefore, the religious paradigm has great value in achieving the goals of globalization and assuming a complete attitude. For realization of these purposes, it is necessary to consider that poly-confessional modern society demands peaceful co-existence of religions and their active interaction in the interests of the world community. The irreversibility of globalization processes causes some positive consequences for religions and cultures and demands the analysis and the decision regarding the problem of choosing the way of integration into the global community.

Nowadays, each state faces the question how to develop in the conditions of the globalizing world.This 
question is also urgent for the Islamic countries, as their participation in the globalization processes makes serious impact on the formation of the world order. It is necessary to notice that the strengthening of the globalization processes is not to the detriment of Islam. On the contrary, it brings advantage since the openness of the world space for globalization allows geographical spread of Islam. Thus, the concept of the Islamic world has now accomplished its geographical measurement. It is possible to say that thanks to globalization, the Islamic world became not so much the community of the countries of the Moslem doctrine distribution zone, as ex-territorial and religious-political phenomenon which forms the global Islamic community for the purpose of Muslim countries development. Accordingly, a natural consequence of the globalization is the deterritorialisation of religions. The religion is spread over traditional faiths, political, cultural and civil borders. At the present time, any religion finds adherents where they never were historically, and loses them in regions of the traditional distribution.

Islam is a dynamically developing religion, which is confirmed by the increasing number of its adherents. Islam today is present in more than 120 countries and it ranks second in the world, after Christianity, in the number of believers - 1,3 billion followers. Muslims represent the majority of the population in more than 40 countries. The largest Muslim state is Indonesia with 210 million; 150 million Muslims live in Pakistan, in India - 140 million, in Bangladesh - 110 million, in Nigeria - 80 million, in Iran - 65 million, in Turkey - 65 million, and in Egypt - 60 million. In the majority of the Middle East states (and in some African countries where Muslims represent a considerable part of the population), Islam is declared the state religion.

Islam has kept the viability, identity and its religiouscultural tradition through many centuries, therefore it is perceived as a counterbalance to other development programs. This religion promotes the independence of the national states and plays an increasingly appreciable role on the international scene. Islam is not regarded only as a belief in God, for Islam instructions penetrate all life aspects of a Muslim from birth to death, defining in many respects his/her social behaviour, character of economic relations, government forms, social structure, etc. The appeal of Islam stands for its refusal of asceticism, in prompting each Muslim to conduct counterbalanced and healthy way of life. It defines the meaning of the life and its valuable reference points. In the Holy Koran, the question of meaning of life and its valuable reference points are not left open for discussions: "And I have not created the jinn and the men except that they should serve Me" (the Holy Koran, 51:56). This sense gives the chance to a person to feel complete, alive, it helps us to perceive and understand the actions and the world around us, and what is especially important, to enter in a dialogue with this world. Nonsense devastates, doing it is impractical. According to the Holy Koran, the Muslim should not be a detached onlooker of occurring processes: he should create on his way to Truth, think, reflect, and analyze signs of the Lord. Accordingly, Islam possesses considerable potential for drawing attention of a society and each individual to the world scale problems and the more so, to the globalization processes, which are connected with changing of modern communities. Each person possesses the ability to independently choose the character of political, economic and social relations: "And say: The truth is from your Lord, so let him who please believe, and let him who please disbelieve" (the Holy Koran, 18:29).

The concept of Islamic religion is different from the religion in the West, as for Muslims there is no disagreement between the policy and the religion in any sense. The policy and religion are two parts of a single whole, which is regulated by the law (Shariyat), attributed to the Allah. For this reason, any attempt to build not Islamic order in Islam can exist only until it is strong enough to contain Islamic growth. In case of following any development model, the question in a Muslim community is not whether the religion should rationalize functioning of state and societal structures, but to what degree and rate it will occur, and what purposes are authorized by the religion.

As time has shown, the West has underestimated the influence of Islam on the broad masses in the Muslim countries and potentials of this religion as a mobilizing and integrating social force. However, already at the beginning of 80 s of the XX century, attitudes of politicians and scientists towards Islam have radically changed. In spite of the fact that the Muslim countries have appeared, to a certain degree, on the periphery of the post industrial world, Islam endures rough revival at present. The Muslim Diasporas living in the West, despite powerful external influence, frequently only become stronger in their own identity. Besides, various centres of power already tried to realize "the absorption" scenario in the XX century, unsuccessfully as practice has shown. Against this strengthening of the Islamic factor in the world, the existence of interaction and conflict of the Islamic world and the globalization is emphasised. The principal cause of this is the intention to impose western liberal values to the Islamic world. Now, the Muslim community actually stands alone against the West and its strategic interests, and therefore Islam 
becomes not only the factor of maintaining its internal solidarity, but also an answer to the threat to the existence of civilization. As a paradox, the globalization has a contradictory effect: it stimulates awakening and modernization of the Islamic world on the basis of its own ideologically-theoretical foundation rethought in the context of the present.

Globalization gradually changes cultural traditions of nations and peoples, transferred from generation to generation. In this context, Islam is an attractive original force which can unite people and help them resist the western culture. The distinctive feature of Islamic consciousness is "Tajweed", i.e. improvement, through returning to sources, renewal. Therefore, any modernization, in any Muslim society, faces an Islamic paradigm of improvement. Novelty and conformity to time have no of independent value in Islam without correlation with the basis, which is initially established in the Revelation.

Considering the issues of the globalization and Islam in preventing their interference and interaction, in our opinion, is extremely urgent as the mankind already faces the creation of the global world community, and global problems following from these processes and crises can change the world picture in an absolutely unpredictable manner. To reduce this unpredictability, it is necessary to establish relations between the individual and the society, between the society and the environment, between various societies and civilizations, it is necessary to solve the matter of law and power, which is one of the globalization cornerstones. The possession of the power means the control over human resources (first of all their world-view), material resources and their distribution. The possession of the law (including the power) in Islam is assumed rather simply: all belongs to the Allah. A basic principle of Islam: human beings — individually and collectively — should share among themselves all rights to sovereignty, the legislation and realization of the power over others. Accordingly, the post structure of global Islamic community is possible only on the basis of the law sent by God through Its Prophet.

The guiding star of the globalization and the consolidation of the Muslim community will be the doctrine about the absolute power of God. It should not be forgotten that according to the Holy Koran "Allah's is the kingdom of the heavens and the earth, and Allah has power over all things" (the Holy Koran, 3:189); “Allah's is the kingdom of the heavens and the earth and what is between them; He creates what He pleases; and Allah has power over all things" (the Holy Koran, 5:17) "And blessed is He Whose is the kingdom of the heavens and the earth and what is between them, and with Him is the knowledge of the hour, and to Him shall you be brought back" (the Holy Koran, 43:85). "And your Lord is the Self-sufficient one, the Lord of mercy; if He pleases, He may take you off, and make whom He pleases successors after you, even as He raised you up from the seed of another people" (the Holy Koran, 6:133) "He it is Who has made you successors in the land and raised some of you above others by (various) grades, that $\mathrm{He}$ might try you by what He has given you" (the Holy Koran, 6:165) (Korganashvili, 2008).

\section{CONCLUSION}

Tourism in Azerbaijan began its development during the Great Silk Road, but special urgency for its development emerged only recently. Azerbaijan is an Islamic state that has significant resources for the development of religious tourism, one of the most profitable types of tourism. The analyses of possibilities for Azerbaijan's participation in the globalization processes and the development of religious tourism have revealed great opportunities for the expansion of interreligious and intercultural dialogues, which can become the basis for building new inter-civilianisation "bridges" and minimizing contradictions between religions.

\section{REFERENCES}

Azstat. Retrieved 15 May 2017 from http://www.stat.gov. az/source/demoqraphy/index- en.php.

Azstat. Retrieved 20 May 2017 from http://www.stat. gov.az/source/tourism/indexen. php.

Korganashvili, L., Mammadova N. (2008). Globalization and Islam: Interaction and Counteraction Problems. International Interuniversity Collection of Scientific Works. V, 98-109.

The Law of the Republic of Azerbaijan "On Freedom of Religious Belief". http://www.e-qanun.az/framework/7649. Constitution of the Republic of Azerbaijan. Retrieved 15 May 2017 from http://www. azerbaijan.az/portal/General/Constitution/doc/ constitution_r.pdf.

The Holy Koran. Retrieved 16 May 2017 from http:// www.aaiil.org/text/hq/trans/ma_list.shtml.

WB-World Bank. Retrieved 16 May 2017 from http:// data.worldbank.org/indicator/ NY.GDP.PCAP. $\mathrm{CD}$ ?view $=$ chart.

WTTC - World Travel \& Tourism Council. Travel \& tourism economic impact 2017, Azerbaijan. Retrieved 15 May 2017 from https:// www.wttc.org/-/ media/files/reports/economic-im- pact-research/ countries-2017/azerbaijan2017.pdf.

Рустамова Э. (2016). В Азербайджане наблюдается туристический бум. http://www.echo.az/article. php?aid=103911. 